\section{Protonation of Nitrofurantoin and Furazidine Molecules in Acidic Media- Molecular Modelling Studies}

\section{Abstract}

The molecular modeling studies on protonation sites of Nitrofurantoin and Furazidine as well as on the stability of particular protonated forms were performed using quantum chemical MP2 method. Performed calculations show that Furazidine oxygen and nitrogen atoms are better proton acceptors than in Nitrofurantoin, therefore the acidity of the media may differentiate Nitrofurantoin and Furazidine antibacterial activity.

Keywords: Nitrofurantoin; Furazidine; Acidity; Protonation sites; Urinary tract infection; Molecular modelling

Received: September 19, 2018; Accepted: October 08, 2018; Published: October 15, 2018

\section{Introduction}

According to literature data in nitrofuran derivatives the major role in antimicrobial activity plays the acidity of physiological medium in urinary tract [1]. It was pointed out [2] that dissociation of Furazidine is hampered in the presence of ascorbic acid (vitamin C). The role of any acidifying agent like ascorbic acid is to prevent alkalization of infected urine and preserve $\mathrm{pH}$ close to 5.5 in which Furazidine molecule stays in non-dissociated form what enhances its antibacterial activity [1]. More acidic medium can probably cause better protonation of the Furazidine molecule than of Nitrofurantoin, what can further enhance Furazidine therapeutic efficacy. Therefore studies of possible protonation sites of Nitrofurantoin and Furazidine, along with stability of particular protonated form, can provide valuable estimate for insight into activity determinates of Furazidine moiety, and also for further modification of its structure. Selection of Nitrofurantoin and Furazidine is a wise model because those part of molecules. Moreover there is distinct difference between their antimicrobial activities. In Escherichia coli test they display MIC $\leq 32 \mu \mathrm{g} / \mathrm{ml}$ and $1 \mu \mathrm{g} / \mathrm{ml}$ for Nitrofurantoin and Furazidine, respectively [3], as reported in information leaflets of medicine present on the market.

\section{Methods}

All quantum chemical calculations were performed with Spartan two compounds differ in two carbon atoms in the rings bridging

\section{Somogi A ${ }^{1 *}$, Dąbrowska $A^{2}$, Ziemba $\mathrm{R}^{3}$ and Pawiński $\mathrm{T}^{1}$}

\section{Department of Drug Chemistry, Medical University of Warsaw, 1 Banacha Str., 02 097 Warsaw, Poland \\ 2 Departments of Cell Biology, National Medicines Institute, 30/34 Chełmska Str., 00-725 Warsaw, Poland \\ 3 Lux Med Group - Medical Center, 51 Prosta Str., 00-838 Warsaw, Poland}

*Corresponding author:
Aleksander Somogi

” aleksander.somogi@wum.edu.pl

Department of Drug Chemistry, Medical University of Warsaw, 1 Banacha Str., 02-097 Warsaw, Poland

Citation: Somogi A, Dąbrowska A, Ziemba R, Pawiński T (2018) Protonation of Nitrofurantoin and Furazidine Molecules in Acidic Media-Molecular Modelling Studies. J In Silico In Vitro Pharmacol Vol. 4 No.2:3.
14 V.1.1.4 software package at the MP2/6-31G*//MP2/6-31G* level [4]. The hydration energies were calculated with SM8 model.

\section{Results and Discussion}

Calculation on neutral Nitrofurantoin tautomer clearly indicates that $\mathrm{N}_{1}-\mathrm{H}$ tautomer is the most stable form both in water medium. The same holds for Furazidine molecule.

The neutral Nitrofurantoin and Furazidine molecules can potentially exist in various tautomeric forms. As shown in Tables $\mathbf{1}$ and 2 the $\mathrm{N}_{1}-\mathrm{H}$ tautomer of Nitrofurantoin is the most stable.

The second most stable tautomer is the one bearing the proton on the $\mathrm{O}_{2}$ nitrogen atom at the MP2/6-31G*//MP2/6-31G* level with hydration energy included Table 1 . Calculation of $\Delta(\Delta \mathrm{Go})$ yields also the $\mathrm{O}_{2}-\mathrm{H}$ tautomer to be the most stable form after the $\mathrm{N}_{1}-\mathrm{H}$ tautomer (Table 2 ). The $\mathrm{N}_{3}-\mathrm{H}$ tautomer probably does not exist. The attached proton is being transferred from $\mathrm{N}_{3}$ to $\mathrm{O}_{2}$ atom during optimization process yielding the $\mathrm{O}_{2}-\mathrm{H}$ tautomer. 
Table 1: Total $\mathrm{MP}_{2} / 6-31 \mathrm{G} * / / 6-31 \mathrm{G} *$ energies, stabilization energies, $\Delta \mathrm{G} 0$ and $\Delta(\Delta \mathrm{G} 0)$ calculated for neutral and protonated Nitrofurantoin molecule.

\begin{tabular}{|c|c|c|c|c|}
\hline Neutral & Total energy & Stabilization energy & $\Delta \mathrm{G}^{0}$ & $\Delta\left(\Delta G^{0}\right)$ \\
\hline $\mathrm{I}\left(\mathrm{N}_{1}-\mathrm{H}\right)$ & -900.956670 & 0.0 & -900.823127 & 0.00 \\
\hline II $\left(\mathrm{N}_{3}-\mathrm{H}\right)$ & -900.919856 & 23.10 & -900.777778 & 28.46 \\
\hline III $\left(\mathrm{O}_{1}-\mathrm{H}\right)$ & -900.928299 & 17.80 & -900.777699 & 28.51 \\
\hline IV $\left(\mathrm{O}_{2}-\mathrm{H}\right)$ & -900.928428 & 17.72 & -900.786946 & 22.70 \\
\hline$V\left(\mathrm{~N}_{2}-\mathrm{H}\right)$ & -900.936229 & 12.83 & -900.793088 & 18.85 \\
\hline VI $\left(\mathrm{O}_{3}-\mathrm{H}\right)$ & -900.869400 & 54.76 & -900.745721 & 48.57 \\
\hline VII $\left(\mathrm{O}_{4}-\mathrm{H}\right)$ & -900.873576 & 52.14 & -900.750943 & 48.57 \\
\hline \multicolumn{5}{|l|}{ Cation } \\
\hline $\mathrm{I}\left(\mathrm{N}_{1}-\mathrm{H} ; \mathrm{O}_{1}-\mathrm{H}\right)$ & -901.208345 & -157.93 & -901.027358 & -128.15 \\
\hline II $\left(\mathrm{N}_{1}-\mathrm{H} ; \mathrm{O}_{2}-\mathrm{H}\right)$ & -901.369024 & -258.75 & -901.132061 & -193.86 \\
\hline III $\left(\mathrm{N}_{1}-\mathrm{H} ; \mathrm{O}_{3}-\mathrm{H}\right)$ & -901.383507 & -267.84 & -901.150271 & -205.28 \\
\hline IV $\left(\mathrm{N}_{1}-\mathrm{H} ; \mathrm{N}_{1}-\mathrm{H}\right)$ & -901.336768 & -238.51 & -901.116485 & -184.08 \\
\hline $\mathrm{V}\left(\mathrm{N}_{1}-\mathrm{H} ; \mathrm{N}_{2}-\mathrm{H}\right)$ & -901.364274 & -255.77 & -901.129443 & -192.21 \\
\hline $\mathrm{VI}\left(\mathrm{N}_{1}-\mathrm{H} ; \mathrm{N}_{3}-\mathrm{H}\right)$ & -901.383523 & -267.85 & -901.150258 & -205.28 \\
\hline VII $\left(\mathrm{N}_{1}-\mathrm{H} ; \mathrm{O}_{4}-\mathrm{H}\right)$ & -901.355919 & -250.53 & -901.135881 & -196.25 \\
\hline VIII $\left(\mathrm{N}_{3}-\mathrm{H} ; \mathrm{O}_{4}-\mathrm{H}\right)$ & -901.315992 & -225.47 & -901.093608 & -169.73 \\
\hline \multicolumn{5}{|l|}{ Dication } \\
\hline $\mathrm{I}\left(\mathrm{N}_{1}-\mathrm{H} ; \mathrm{N}_{1}-\mathrm{H} ; \mathrm{N}_{3}-\mathrm{H}\right)$ & -901.763484 & -506.28 & -901.304039 & -301.77 \\
\hline $\mathrm{II}\left(\mathrm{N}_{1}-\mathrm{H} ; \mathrm{O}_{1}-\mathrm{H} ; \mathrm{N}_{3}-\mathrm{H}\right)$ & -901.785163 & -519.88 & -901.328894 & -317.37 \\
\hline III $\left(\mathrm{N}_{1}-\mathrm{H} ; \mathrm{O}_{2}-\mathrm{H} ; \mathrm{N}_{3}-\mathrm{H}\right)$ & -901.784169 & -519.26 & -901.329481 & -317.74 \\
\hline $\mathrm{IV}\left(\mathrm{N}_{1}-\mathrm{H} ; \mathrm{N}_{1}-\mathrm{H} ; \mathrm{O}_{2}-\mathrm{H}\right)$ & -901.733673 & -487.57 & -901.289431 & -292.61 \\
\hline$V\left(\mathrm{~N}_{1}-\mathrm{H} ; \mathrm{O}_{1}-\mathrm{H} ; \mathrm{O}_{2}-\mathrm{H}\right)$ & -901.767780 & -508.97 & -901.289982 & -292.95 \\
\hline VI $\left(\mathrm{N}_{1}-\mathrm{H} ; \mathrm{N}_{1}-\mathrm{H} ; \mathrm{N}_{2}-\mathrm{H}\right.$ & -901.727780 & -483.87 & -901.246460 & -265.64 \\
\hline VII $\left(\mathrm{N}_{1}-\mathrm{H} ; \mathrm{N}_{2}-\mathrm{H} ; \mathrm{N}_{3}-\mathrm{H}\right)$ & -901.762048 & -505.37 & -901.296180 & -296.84 \\
\hline VIII $\left(\mathrm{N}_{1}-\mathrm{H} ; \mathrm{N}_{2}-\mathrm{H} ; \mathrm{O}_{1}-\mathrm{H}\right)$ & -901.482729 & -330.10 & -901.220942 & -249.63 \\
\hline $\mathrm{IX}\left(\mathrm{N}_{1}-\mathrm{H} ; \mathrm{N}_{2}-\mathrm{H} ; \mathrm{O}_{2}-\mathrm{H}\right)$ & -901.734154 & -487.87 & -901.254361 & -270.60 \\
\hline
\end{tabular}

Table 2: Total $\mathrm{MP}_{2} / 6-31 \mathrm{G} * / / 6-31 \mathrm{G} *$ energies, stabilization energies, $\Delta \mathrm{G} 0$ and $\Delta(\Delta \mathrm{G} 0)$ calculated for neutral and protonated Furazidine molecule.

\begin{tabular}{|c|c|c|c|c|}
\hline Neutral & Total energy & Stabilization energy & $\Delta \mathrm{G}^{0}$ & $\Delta\left(\Delta G^{0}\right)$ \\
\hline $\mathrm{I}\left(\mathrm{N}_{1}-\mathrm{H}\right)$ & -978.101505 & 0.00 & -977.934728 & 0.00 \\
\hline II $\left(\mathrm{N}_{3}-\mathrm{H}\right)$ & -978.047774 & 33.72 & -977.883044 & 32.43 \\
\hline III $\left(\mathrm{O}_{1}-\mathrm{H}\right)$ & -978.079351 & 13.90 & -977.896975 & 23.69 \\
\hline $\mathrm{IV}\left(\mathrm{O}_{2}-\mathrm{H}\right)$ & -978.073821 & 17.37 & -977.898060 & 23.01 \\
\hline$V\left(\mathrm{~N}_{2}-\mathrm{H}\right)$ & -978.065152 & 22.81 & -977.903567 & 19.55 \\
\hline $\mathrm{VI}\left(\mathrm{O}_{3}-\mathrm{H}\right)$ & -978.011941 & 56.20 & -977.856693 & 48.97 \\
\hline VII $\left(\mathrm{O}_{4}-\mathrm{H}\right)$ & -978.011940 & 56.20 & -977.856734 & 48.94 \\
\hline \multicolumn{5}{|c|}{ Cation } \\
\hline $\mathrm{I}\left(\mathrm{N}_{1}-\mathrm{H} ; \mathrm{O}_{1}-\mathrm{H}\right)$ & -978.497706 & -248.62 & -978.236155 & -118.53 \\
\hline II $\left(\mathrm{N}_{1}-\mathrm{H} ; \mathrm{O}_{2}-\mathrm{H}\right)$ & -978.501750 & -251.15 & -978.252367 & -199.32 \\
\hline III $\left(\mathrm{N}_{1}-\mathrm{H} ; \mathrm{O}_{3}-\mathrm{H}\right)$ & -978.501737 & -251.15 & -978.252361 & -199.31 \\
\hline IV $\left(\mathrm{N}_{1}-\mathrm{H} ; \mathrm{N}_{1}-\mathrm{H}\right)$ & -978.483563 & -239.74 & -978.230392 & -185.53 \\
\hline$V\left(\mathrm{~N}_{1}-\mathrm{H} ; \mathrm{N}_{2}-\mathrm{H}\right)$ & -978.510679 & -256.76 & -978.250115 & -198.55 \\
\hline $\mathrm{VI}\left(\mathrm{N}_{1}-\mathrm{H} ; \mathrm{N}_{3}-\mathrm{H}\right)$ & -978.538595 & -274.27 & -978.274167 & -213.00 \\
\hline VII $\left(\mathrm{N}_{1}-\mathrm{H} ; \mathrm{O}_{4}-\mathrm{H}\right)$ & -978.499000 & -249.43 & -978.249830 & -197.73 \\
\hline VIII $\left(\mathrm{N}_{3}-\mathrm{H} ; \mathrm{O}_{4}-\mathrm{H}\right)$ & -978.460211 & -225.09 & -978.215781 & -176.36 \\
\hline \multicolumn{5}{|c|}{ Dication } \\
\hline $\mathrm{I}\left(\mathrm{N}_{1}-\mathrm{H} ; \mathrm{N}_{1}-\mathrm{H} ; \mathrm{N}_{3}-\mathrm{H}\right)$ & -978.913382 & -509.45 & -978.438447 & -316.08 \\
\hline $\mathrm{II}\left(\mathrm{N}_{1}-\mathrm{H} ; \mathrm{O}_{1}-\mathrm{H} ; \mathrm{N}_{3}-\mathrm{H}\right)$ & -978.940486 & -526.46 & -978.466285 & -333.55 \\
\hline III $\left(\mathrm{N}_{1}-\mathrm{H} ; \mathrm{O}_{2}-\mathrm{H} ; \mathrm{N}_{3}-\mathrm{H}\right)$ & -978.937012 & $-524,28$ & -978.463007 & -331.50 \\
\hline $\mathrm{IV}\left(\mathrm{N}_{1}-\mathrm{H} ; \mathrm{N}_{1}-\mathrm{H} ; \mathrm{O}_{2}-\mathrm{H}\right)$ & -978.878684 & -487.68 & -978.434441 & -313.57 \\
\hline $\mathrm{V}\left(\mathrm{N}_{1}-\mathrm{H} ; \mathrm{O}_{1}-\mathrm{H} ; \mathrm{O}_{2}-\mathrm{H}\right)$ & -978.899957 & -501.03 & -978.403282 & -294.02 \\
\hline $\mathrm{VI}\left(\mathrm{N}_{1}-\mathrm{H} ; \mathrm{N}_{1}-\mathrm{H} ; \mathrm{N}_{2}-\mathrm{H}\right.$ & -978.866915 & -480.29 & -978.370630 & -273.53 \\
\hline VII $\left(\mathrm{N}_{1}-\mathrm{H} ; \mathrm{N}_{2}-\mathrm{H} ; \mathrm{N}_{3}-\mathrm{H}\right)$ & -978.914768 & -510.32 & -978.431724 & -311.86 \\
\hline VIII $\left(\mathrm{N}_{1}-\mathrm{H} ; \mathrm{N}_{2}-\mathrm{H} ; \mathrm{O}_{1}-\mathrm{H}\right)$ & -978.894982 & -497.91 & -978.395595 & -289.19 \\
\hline VIII $\left(\mathrm{N}_{1}-\mathrm{H} ; \mathrm{N}_{2}-\mathrm{H} ; \mathrm{O}_{2}-\mathrm{H}\right)$ & -978.874654 & -485.15 & -978.380531 & -279.94 \\
\hline
\end{tabular}


When proton is placed on $\mathrm{O}_{3}$ oxygen atom then it relocates to one of the atoms of the nitro group. The relative stability of Nitrofurantoin tautomers in water medium is as: $\mathrm{N} 1-\mathrm{H}>\mathrm{O}_{2}-\mathrm{H}>\mathrm{O}_{1}$ $\mathrm{H}>\mathrm{O}_{4}-\mathrm{H}$ form. The same trend is observed when the $\Delta(\Delta \mathrm{Go})$ values are considered.

In the case of Furazidine molecule also the $\mathrm{N}_{1}-\mathrm{H}$ tautomer appeared to be the most stable. Here however the $\mathrm{N}_{2}-\mathrm{H}$ and $\mathrm{N}_{3}-\mathrm{H}$ tautomers exist. The $\mathrm{N}_{3}-\mathrm{H}$ tautomer is stabilized through $\mathrm{C}-\mathrm{H}$ interaction of more flexible bridging chain with $\mathrm{O}_{2}$ atom of five membered rings. As in Nitrofurantoin, when proton is placed on $\mathrm{O}_{3}$ oxygen atom then it relocates to one of the atoms of the nitro group.

In Nitrofurantoin and Furazidine molecules there is 8 potential protonation centers, 3 oxygen atoms and 3 nitrogen atoms and two oxygen atoms of the nitro group (Figure 1). Nevertheless the nitro group, in each of two equivalent resonance structures, can potentially interact via the hydrogen bonding.

Protonation of neutral form yields mostly the other than $\mathrm{H}-\mathrm{N}_{1}-\mathrm{H}+$ cations what prevents the change of charge distribution and electrostatic potential pattern around non ionized fragment of neutral molecule believed to be necessary for Furazidine activity.

For Nitrofurantoin molecule the most stable is the $\mathrm{N}_{1}-\mathrm{H} ; \mathrm{N}_{3}-\mathrm{H}$ cation. The $\mathrm{N}_{1}-\mathrm{H} ; \mathrm{O}_{3}-\mathrm{H}$ cation rearranges also to that tautomer (Figure 1). For Furazidine molecule cation $\mathrm{N}_{1}-\mathrm{H} \mathrm{O} \mathrm{O}_{3}-\mathrm{H}$ does not exist because it rearranges to $\mathrm{N}_{1}-\mathrm{H} ; \mathrm{O}_{2}-\mathrm{H}$ tautomer. The most stable like in Nitrofurantoin stays the $\mathrm{N}_{1}-\mathrm{H} ; \mathrm{N}_{3}-\mathrm{H}$ form Table 2.

The dication of Nitrofurantoin with the highest stability is the one formed from the most stable $\mathrm{N}_{1}-\mathrm{H} ; \mathrm{N}_{3}-\mathrm{H}$ cation by protonation of $\mathrm{O}_{1}$ or $\mathrm{O}_{2}$ oxygen atom. The same holds for Furazidine molecule (Table 1).

Formation of the most stable monocation $\mathrm{N}_{1}-\mathrm{H} \mathrm{N} \mathrm{N}_{3}-\mathrm{H}$ is more preferred in Furazidine then in Nitrofurantoin by ca. $7.75 \mathrm{kcal} /$ mole. The most stable dication of Nitrofurantoin is $\mathrm{N}_{1}-\mathrm{H} ; \mathrm{O}_{2}-\mathrm{H} ; \mathrm{N}_{3}-$ $\mathrm{H}$, however very close in energy to $\mathrm{N}_{1}-\mathrm{H} ; \mathrm{O}_{1}-\mathrm{H} ; \mathrm{N}_{3}-\mathrm{H}$. In Furazidine molecule formation of intramolecular hydrogen bonding yields the $\mathrm{N}_{1}-\mathrm{H} ; \mathrm{O}_{2}-\mathrm{H} ; \mathrm{N}_{3}-\mathrm{H}$ dication the most stable. This is due to the higher flexibility of the bridging chain, than in Nitrofurantoin.

The nitro group can be protonated at each of the oxygen atoms yielding resonance structure $-\mathrm{NOOH}+$ similar to $-\mathrm{COOH}$ [4]. Further protonation of $-\mathrm{NO}_{2}$ could lead to reduction of $-\mathrm{NO}_{2}$ yielding the $-\mathrm{NH}_{2}$ derivative. This is one of the mechanisms that activate Furazidine active substance in the living organism $[5,6]$.

If additional proton is placed on $\mathrm{O}_{3}$ oxygen of five membered ring of neutral Furazidine, then it relocates to $\mathrm{O}_{2}$ oxygen atom. It means that formation of cation III is very unlikely. Cation II gets additional stabilization due to intramolecular bonding with one of the oxygen atoms of $-\mathrm{NO}_{2}$ group. The most stable cation is the $\mathrm{N}-{ }_{1} \mathrm{H}, \mathrm{N}_{3}-\mathrm{H}$. The total energy and thermodynamics $(\Delta \mathrm{G})$ analysis leads to the same conclusions.

Similar conclusions regarding possible protonation sites appear from analysis of electron charges on the atoms that are eager to accept proton (Table 3).

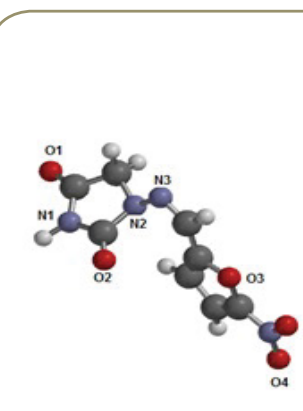

(A)

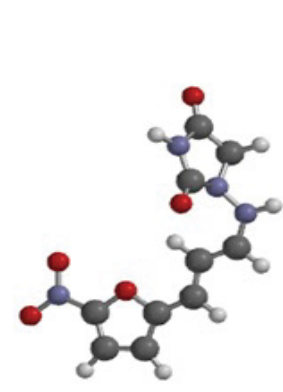

(A)

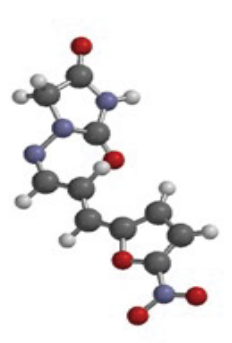

(B)
Neutral N1-H

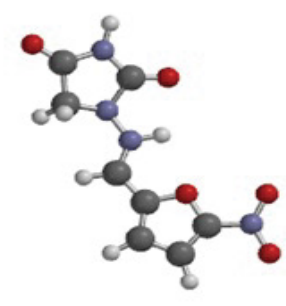

(B)

Cation N1-H; N3-H

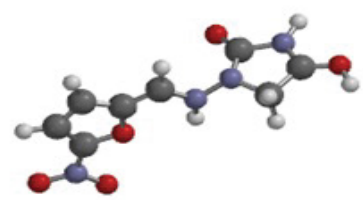

(A)

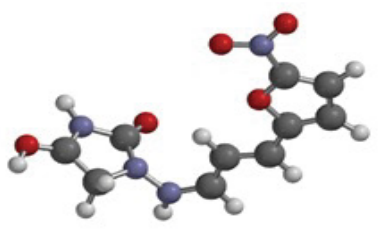

(B)

Dication N1-H; 01-H; N3-H

Figure 1 The most stable neutral and protonated forms of Nitrofurantoin (A) and Furazidine (B) molecules.

For neutral Nitrofurantoin and Furazidine nitrogen atoms the most negative is the $\mathrm{N}_{3}$ atom of the bridging chain. Protonation at this atom leads to the most stable $\mathrm{N}_{1}-\mathrm{H} ; \mathrm{N}_{3}-\mathrm{H}$ cationic form. In the cation the most negatively charge atoms yield the most stable $\mathrm{N}_{1}$ $\mathrm{H} ; \mathrm{O}_{1}-\mathrm{H} ; \mathrm{N}_{3}-\mathrm{H}$ dicationic form of Nitrofurantoin, and $\mathrm{N}_{1}-\mathrm{H} ; \mathrm{O}_{1}-\mathrm{H}$; $\mathrm{N}_{3}-\mathrm{H}$ dicationic form of Furazidine, respectively.

Consequently the $\mathrm{N}_{1}-\mathrm{H}$ tautomer of neutral Furazidine is more stable than $\mathrm{N}_{3}-\mathrm{H}, \mathrm{O}_{1}-\mathrm{H}$ and $\mathrm{O}_{2}-\mathrm{H}$ tautomers. Performed calculations show that Furazidine oxygen and nitrogen atoms are good proton acceptors. Therefore it is justified to supplement Furazidine treatment with weak acids, for instance vitamin C, to keep the protonated Furazidine at satisfactory level, preventing urine alkalization. The in vitro studies on Furazidine acidity as function of $\mathrm{pH}$ are underway. 
Table 3: Electrostatic, Mulliken and natural charges calculated for nitrofurantoin and furazidine at $\mathrm{MP}_{2} / 631 \mathrm{G} * / / \mathrm{MP}_{2} / 6-31 \mathrm{G} *$ level.

\begin{tabular}{|c|c|c|c|c|c|c|}
\hline \multicolumn{7}{|c|}{ Atomic Charges } \\
\hline \multicolumn{7}{|c|}{ Nitrofurantoin } \\
\hline \multicolumn{7}{|c|}{ Neutral $\mathrm{N}_{1}-\mathrm{H}$ Cation $\mathrm{N}_{1}-\mathrm{H} ; \mathrm{N}_{3}-\mathrm{H}$} \\
\hline Atom & Electrostatic & Mulliken & Natural & Electrostatic & Mulliken & Natural \\
\hline $\mathrm{N}_{1}$ & -0.718 & -0.731 & -0.701 & -0.544 & -0.737 & -0.689 \\
\hline $\mathrm{N}_{2}$ & -0.009 & -0.444 & -0.375 & -0.229 & -0.371 & -0.310 \\
\hline $\mathrm{O}_{1}$ & -0.483 & -0.447 & -0.555 & -0.404 & -0.419 & -0.527 \\
\hline $\mathrm{O}_{2}$ & -0.461 & -0.428 & -0.529 & -0.377 & -0.356 & -0.458 \\
\hline $\mathrm{N}_{3}$ & -0.314 & -0.195 & -0.237 & +0.215 & -0.340 & -0.228 \\
\hline $\mathrm{O}_{3}$ & -0.237 & -0.441 & -0.401 & -0.210 & -0.462 & -0.416 \\
\hline $\mathrm{N}_{4}$ & +0.676 & +0.276 & +0.437 & +0.631 & $+0.281+0.426$ & +0.426 \\
\hline $\mathrm{O}_{4}$ & -0.356 & -0.330 & -0.327 & -0.310 & -0.298 & -0.295 \\
\hline $\mathrm{O}_{5}$ & -0.389 & -0.342 & -0.345 & -0.318 & -0.289 & -0.291 \\
\hline \multicolumn{7}{|c|}{ Furazidine } \\
\hline \multicolumn{7}{|c|}{ Neutral $\mathrm{N}_{1}-\mathrm{H}$ Cation $\mathrm{N}_{1}-\mathrm{H} ; \mathrm{N}_{3}-\mathrm{H}$} \\
\hline Atom & Electrostatic & Mulliken & Natural & Electrostatic & Mulliken & Natural \\
\hline $\mathrm{N}_{1}$ & -0.663 & -0.731 & -0.699 & -0.617 & -0.728 & -0.695 \\
\hline $\mathrm{N}_{2}$ & +0.013 & -0.439 & -0.369 & -0.132 & -0.422 & -0.372 \\
\hline $\mathrm{O}_{1}$ & -0.459 & -0.459 & -0.568 & -0.429 & -0.418 & -0.530 \\
\hline $\mathrm{O}_{2}$ & -0.451 & -0.433 & -0.533 & -0.401 & -0.372 & -0.474 \\
\hline $\mathrm{N}_{3}$ & -0.347 & -0.220 & -0.246 & -0.026 & -0.379 & -0.305 \\
\hline $\mathrm{O}_{3} 2$ & -0.265 & -0.405 & -0.405 & -0.202 & -0.438 & -0.401 \\
\hline $\mathrm{N}_{4}$ & +0.681 & +0.275 & +0.437 & +0.653 & +0.279 & +0.427 \\
\hline $\mathrm{O}_{4}-0.362$ & -0.362 & -0.334 & -0.332 & -0.328 & -0.307 & -0.304 \\
\hline$O_{5}-0.393$ & -0.393 & -0.346 & -0.349 & -0.335 & -0.298 & -0.300 \\
\hline
\end{tabular}

\section{References}

1. Katzung BG (2015) Basic and Clinical Pharmacology. Lange Medical Books/McGraw-Hill.

2. Axelrod DL (1985) Ascorbic Acid and Urinary pH. JAMA 254: 13101311.

3. Mannisto $P$, Karttunen $P$ (1979) Pharmacokinetics of furagin, a new Nitrofurantoin congener on human volunteers. Int J Pharmacol Biopharm 17: 264-270.
4. Hehre WJ, Yu J, Klunzinger PE, Lou L (2014) Spartan Pro. Wavefunction Inc. Irvine, Spartan 1.

5. Exner O, Bohm S (2005) Protonated nitro group: structure, energy and conjugation. Org Biomolec Chem 3: 1838-1843.

6. McOsker CC, Fitzpatrick PM (1994) Nitrofurantoin: Mechanism of action and implications for resistance development in common uropathogens. J Antimicrob Chemother 33: 23-30. 